\title{
Engaging students in inquiry learning at The Big Dig, Sydney
}

Louise Zarmati, Lecturer in Humanities and Social Sciences, School of Education, University of Tasmania, Launceston, Tasmania, Australia.

e-mail: louise.zarmati@utas.edu.au

Alison Frappell, Education and Interpretation Officer, Sydney Harbour YHA and The Big Dig Archaeology Education Centre, The Rocks, Sydney, Australia

e-mail: thebigdig@yha.com.au

\begin{abstract}
Since opening in 2010, The Big Dig Archaeology Education Centre in Sydney has welcomed over 70,000 students aged 5 to 18 years to participate in school learning programs. Students use the process of inquiry to 'work like an archaeologist' in purpose-built classrooms on a site which spans the Colonial to Federation periods of Australian history (1795-1914). Using data collected from teacher evaluations we identify four key factors that contribute to successful learning for students in our archaeology programs.
\end{abstract}

Résumé: Depuis son ouverture en 2010, le centre d'éducation archéologique Big Dig à Sydney a accueilli plus de 70,000 élèves âgés de 5 à 18 ans pour participer à nos programmes d'apprentissage scolaire. Les élèves utilisent le 'processus d'enquête' pour 'travailler comme un archéologue' dans des salles de classe spécialement crées sur un vrai site archéologique de la période coloniale australienne à la Fédération (1795-1914). En utilisant les données recueillies à partir des évaluations des enseignants, nous identifions quatre facteurs clés qui expliquent la réussite de notre programme scolaire.

Resumen: Desde su apertura en 2010, el Centro de Educación Arqueológica Big Dig en Sydney ha recibido a más de 70,000 estudiantes de entre 5 y 18 años para participar en nuestros programas de aprendizaje escolar. Los estudiantes utilizan el 'proceso de consulto' para 'trabajar como arqueólogos' en aulas especialmente creadas en un sitio arqueológico real desde el período colonial australiano hasta la Federación (1795-1914). Usando los datos recopilados de las evaluaciones de los maestros, identificamos cuatro factores clave que explican el éxito de nuestro programa escolar.

\section{KEY WORDS archaeology, history, pedagogy, simulation, digging, students, inquiry}

\section{Introduction}

Since The Big Dig Archaeology Education Centre opened in 2010 over 70,000 school students have participated in archaeology education programs in its two purpose-built classrooms. In the first section of this paper, archaeology education consultant Louise Zarmati describes the historical and archaeological background of the Big Dig site and explains why and how she developed the Archaeology Education Centre's learning programs. In the second section, 
Alison Frappell discusses feedback provided by teachers about the impact of the learning experiences on their students. Teachers identified four key factors that made their students' learning experience effective and worthwhile: alignment to the Australian Curriculum; visiting a 'real' archaeological site; working like an archaeologist and participating in inquiry learning.

\section{Background History}

Sydney Harbour YHA (Youth Hostels Australia) is located in Sydney's historic precinct of The Rocks. Tucked between the Harbour Bridge and Circular Quay, with spectacular views of the Opera House and Sydney Harbour, it is a picturesque and much photographed area. Its quaint mixture of nineteenth and early twentieth century buildings, narrow laneways and steep stairways, restaurants, cafes, bars and shops make it a popular destination for local, interstate and international tourists.

The Rocks area has a long history of human occupation. The area was used by Aboriginal people for thousands of years prior to European settlement because the rocky outcrop of Tallawoladah (The Rocks) once provided a clear view to the harbour area of Warrane (Sydney Cove) below. An archaeological deposit at the nearby Lilyvale site provides evidence for a date of around $500 \mathrm{BP}$ when Aboriginal people cooked a meal of snapper and mussels on the rocky ridge overlooking the harbour (Karskens 1999:25).

The first British settlement of the site occurred around 1795. By 1800 The Rocks had become a chaotic arrangement of roughly-built houses and huts inhabited by convicts and exconvicts. By 1859 , thirty to fifty small but solid houses had been constructed on the rocky outcrop with a spectacular view of Sydney Harbour.

Following an outbreak of bubonic plague in The Rocks and public protest against 'slum' housing conditions, the New South Wales (NSW) government resumed almost all the land in The Rocks, including the Cumberland/Gloucester Streets site, and demolished all the buildings between 1902 and 1915. The land was then used for a variety of purposes, including light industry and from the 1960s as a parking lot for government buses and other vehicles. Preliminary archaeological and historical research confirmed the existence of a comprehensive heritage resource that warranted further investigation.

In 1994 Sydney Cove Authority engaged a team of archaeologists from heritage consultants Godden Mackay Logan to undertake a comprehensive archaeological investigation of the 2,675 square metre site. A team of over twenty archaeologists excavated the remains of 42 buildings and over 750,000 artefacts. Hundreds of Sydneysiders came to watch, and 400 hundred people volunteered to excavate. The site became a popular attraction during the six-month dig and soon became affectionately known as 'The Big Dig', the name by which it is known today. The 1994 excavation has made a significant contribution to our knowledge of Australian colonial history by challenging the traditional "ball-and-chain' view of Sydney's convict history and the popular belief that The Rocks was an urban slum in the later 19th century. The physical remains revealed much about the evolution of Sydney as a city, evidence not available from written sources of the time. 


\section{Public Interest in Archaeology}

The Cumberland/Gloucester Streets excavation attracted an extraordinary level of public interest and received extensive coverage in the media. Public engagement was encouraged, and the people of Sydney were able to observe the process of excavation with great interest from a raised platform that was constructed on the Gloucester Street side of the site and during regular site tours.

Project historian Grace Kaskens attributed the large crowds not only to people's fascination with "the notion of buried treasure", but to a "sense of connectedness with the past, the immediacy of the physical, the tactile dimension, the recognition that though these generations of people have gone forever, they nevertheless left behind all these places, spaces and things" (Karskens 1999:17).

\section{Significance of the Site}

Under the wider protection of the NSW State Government Heritage Act of 1977, The Big Dig site was added to the State Heritage register in 2010. In the statement of significance, justifying the inclusion of the site on the register, it noted that it is one of the few surviving places in The Rocks with a physical connection to the first British settlement, where "the substantial physical evidence of the site has distinctive visual qualities and evocative capacity". It was further noted that the site has "a unique ability to provide 'hands on' experience of important phases of Sydney's history and development and has high interpretative and educational potential" (NSW Government 2016). For this reason, NSW Heritage and Sydney Harbour Foreshore Authority decided to conserve the site and open it to the public rather than allow it to be developed by private interests.

To date the Big Dig is the largest urban excavation to have taken place in Sydney. It has provided an extraordinary material record of urban life in Sydney during the Colonial, Victorian, Edwardian and Federation periods (ca.1795-1914) that is of great significance in Australian history in general.

\section{Post-excavation Development, 2006-2009}

Following the excavations in 1994 the site was closed to the public for 15 years. In 2006, YHA won the tender to develop the site and then worked with the site's owners, Sydney Harbour Foreshore Authority (SHFA, now Place Management NSW, Property NSW), to construct the youth hostel on the Cumberland and Gloucester streets site. Heritage architects Tzannes Associates designed the building to be raised off the ground on pillars so that it 'floats' above the site, therefore preserving the important archaeological remains below. Different parts of the building are designed to 'wrap-around' the archaeological remnants within its structure, as well as allow public access along the re-established laneways to the archaeological site. Interpretation panels, historic streetscape images, interpretive brochures and the creation of special interpretation spaces within selected excavated building footings have been incorporated into the structure. Original artefacts are displayed in museum cases positioned near their original find-spots. 
During the planning of the hostel, YHA realised that many groups visiting The Big Dig site would not be from Sydney, so it was important to provide affordable hostel accommodation, especially for school groups. For this reason, dedicated group facilities were included in the design of the hostel.

Sydney Harbour YHA opened its doors to guests in November 2009 and the archaeology education programs for students began in the 2010 school year.

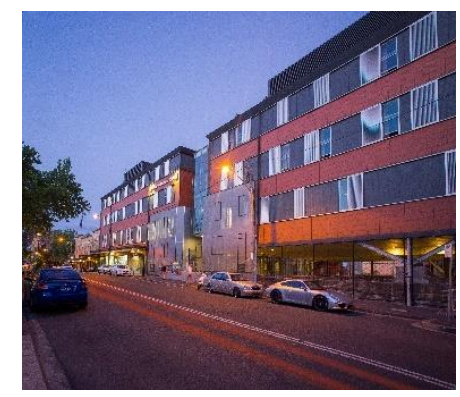

Insert photo Figure 1.:

\section{Designing Archaeology Education Programs for The Big Dig}

One of the factors that set apart the YHA tender proposal was its inclusion of a comprehensive plan to provide educational and cultural experiences for young people. The idea was to attract young people to The Rocks to showcase Sydney's historical and archaeological heritage. The proposal included dedicated learning spaces that would provide archaeology education programs for school students during the school year, and at other times be used for other educational and community events.

YHA's The Big Dig Archaeology Education Centre includes two purpose-built classrooms, with clear views across the foundations of houses and backyards of convicts and free-settlers. Each classroom has the capacity for up to 36 students to learn first-hand about the work of archaeologists on the only authentic archaeological dig open to the public in Sydney.

As part of its commitment to provide quality learning experiences for young people, YHA commissioned archaeology education consultant Louise Zarmati in 2009 to design a suite of archaeology education programs for school students aged 5 to 18 years. These are now delivered by the Sydney Learning Adventures (SLA) guides' team, the educational unit of Place Management NSW which manages The Rocks precinct. Members of the SLA team also work at The Rocks Discovery Museum, where a selection of significant finds from The Big Dig excavation and around The Rocks are displayed.

SLA also offer several Aboriginal educational programs in The Rocks, presented by its Aboriginal guides team. The programs explore Gadigal culture, history and identity, the impact of colonisation on Aboriginal People and the environment, and examine important historical events related to Aboriginal social and political rights. These programs are available to all school students and are promoted as companion programs to The Big Dig archaeology programs. 


\section{Descriptions of The Big Dig Archaeology Education Programs}

The Archaeology Education Programs are aligned to the grade/age groupings of Australian schools. Although archaeology is not taught as a discrete subject in the Australian Curriculum, it is included in the knowledge, understanding and skills of some history topics, and in NSW, students in Years 7 to 10 are required to do a site study as part of their study of history.

Each student is charged a fee of AUD\$14 per program (2019) and most programs run for 2 hours. The fee is paid by students themselves rather than by their school. Fees go towards wages and operating costs, and the programs receive no subsidy or financial support from state or federal governments. Unfortunately, this means that not all schools (and students) have equity of access to this important learning resource.

The majority of schools that visit come from the Sydney metropolitan area and most, especially those located in rural areas, hire buses or coaches to transport students. Travel to the venue is an additional cost that must also be factored into the overall cost of the field trip.

Pre-visit teaching resources are provided on The Big Dig website https://thebigdig.com.au/ to help teachers prepare their students for the learning experience. A new addition in 2019 is an 8-minute video that places the site in its temporal and geographical contexts. One dollar of the accommodation fee paid by each visitor to the hostel contributes to a sinking fund, which is used for development projects, conservation and commissioning resources such as the video for the education programs. We advise teachers to show the video to their students before they visit the site, so they arrive with an understanding of its geographical location in Sydney and how the site developed and changed over time.

\section{Little Diggers (ages 5 to 8 years)}

Students investigate what life was like for children who lived in The Rocks during the 1800s. What were their houses like? What games did they play? How were their lives different from and similar to their own? Students participate in a simulated excavation to retrieve authentic artefacts from the original 1994 excavation, then contextualise them on an interactive 'map mat' of the site to draw conclusions about life in The Rocks during the 19th century.

\section{Dirt Detectives (ages 8 to 10 years)}

Students investigate what life was like for convicts transported to the colony of NSW in the 19 th century. They participate in a simulated excavation to retrieve authentic artefacts from the site and examine them to consider the accuracy of 'ball-and-chain' stories of incarceration, brutal punishment and harsh labour depicted in some history books.

\section{Pieces of the Past (ages 10 to 12 years)}

Students of this age are too big to work in the confined space of the simulated excavation, so all their work is done at tables in the classrooms. They examine artefacts from the 1994 excavation, such as buttons, bottles, buckles and beads to find out about the lives of people who lived in the neighbourhood in the 1800s. They investigate significant people who lived there and how they participated in the development of the colony.

\section{Cesspits and Old Rubbish (ages 12 to 14 years)}

Students conduct an historical inquiry into the methods used by historians and archaeologists investigate history. They examine a range of sources to find out whether The Rocks really was the 'dirty slum' it was described as by contemporary writers. They analyse authentic 
artefacts retrieved from wells, cisterns, cellars and 'dunnies'(toilets) to examine the lives of the more 'colourful' inhabitants of the small houses and narrow lands of this close-knit urban neighbourhood.

\section{Shopfront to Western Front (ages 14 to 16 years)}

This new program, introduced in 2015, examines how industrialisation, imperialism and significant events such as the First World War had an impact on how people in The Rocks lived, worked and thought. Students examine and interpret authentic artefacts, written and pictorial sources to delve into the lives of real families who lived in The Rocks between the mid-nineteenth and early twentieth centuries. This program incorporates historical concepts and skills such as continuity and change, cause and effect, perspective, empathetic understanding and contestability.

\section{Groundwork: Archaeology at The Big Dig (ages 16 to 18 years)}

This is the most sophisticated program on offer because it is aligned to the NSW Senior Ancient and Modern History courses (NESA 2018). Students undertake a critical inquiry to examine how historians and archaeologists investigate, record, reconstruct and interpret the past. Students analyse primary and secondary sources relating to the lives of people who lived and worked in The Rocks in the nineteenth century, and assess the impact of the Industrial Revolution on their everyday lives. They examine ethical issues involved in the excavation, conservation and interpretation of a site and its presentation to the public. In response to teacher requests, this program has now been extended to a full-day offering which extends to other significant historic and archaeological sites in The Rocks.

Student Visitors to The Big Dig Archaeology Education Programs, 2018-2018

Table 1. Total number of students who participated in archaeology education programs, 2010-2018

\begin{tabular}{|l|c|c|c|c|c|c|c|c|c|}
\hline Year & $\mathbf{2 0 1 0}$ & $\mathbf{2 0 1 1}$ & $\mathbf{2 0 1 2}$ & $\mathbf{2 0 1 3}$ & $\mathbf{2 0 1 4}$ & $\mathbf{2 0 1 5}$ & $\mathbf{2 0 1 6}$ & $\mathbf{2 0 1 7}$ & $\mathbf{2 0 1 8}$ \\
\hline $\begin{array}{l}\text { Total } \\
\text { number of } \\
\text { students }\end{array}$ & 3618 & 3761 & 5567 & 8751 & 10194 & 9526 & 10620 & 11924 & 10467 \\
\hline
\end{tabular}

\section{Analysis}

- Numbers steadily increased from opening in 2010 to 2012 as more days were made available for the programs.

- 2013 saw a spike in visitor numbers as the new Australian Curriculum and the NSW History syllabuses containing archaeology were rolled out across the primary and secondary years.

- Numbers have remained steady since 2016 as the new curriculum has become established. 
Table 2. Breakdown of primary versus secondary visitors, 2010-2018

\begin{tabular}{|l|c|c|c|c|c|c|c|c|c|}
\hline Year & $\mathbf{2 0 1 0}$ & $\mathbf{2 0 1 1}$ & $\mathbf{2 0 1 2}$ & $\mathbf{2 0 1 3}$ & $\mathbf{2 0 1 4}$ & $\mathbf{2 0 1 5}$ & $\mathbf{2 0 1 6}$ & $\mathbf{2 0 1 7}$ & $\mathbf{2 0 1 8}$ \\
\hline $\begin{array}{l}\text { Primary } \\
\text { students }\end{array}$ & 1034 & 1583 & 2005 & 5018 & 5226 & 5207 & 7358 & 8296 & 7388 \\
\hline $\begin{array}{l}\text { Secondary } \\
\text { students }\end{array}$ & 2584 & 2178 & 3562 & 3733 & 4968 & 4319 & 3262 & 3628 & 3079 \\
\hline
\end{tabular}

\section{Analysis}

- Up to 2013, the majority of student visitors came from secondary schools.

- 2014 was a turning point when more primary students participated in the programs than secondary students.

- From 2016, the number of primary student visitors more than doubled the number of secondary visitors.

- We attribute this to the fact that more Australian history is taught in primary (Years 3 and 4) than in secondary (Year 9).

- Primary schools may also have more time and flexibility to take students out of school on field trips.

Table 3. Participation in different education programs, 2010 to 2018

\begin{tabular}{|l|c|c|c|c|c|c|c|c|c|}
\hline Year & $\mathbf{2 0 1 0}$ & $\mathbf{2 0 1 1}$ & $\mathbf{2 0 1 2}$ & $\mathbf{2 0 1 3}$ & $\mathbf{2 0 1 4}$ & $\mathbf{2 0 1 5}$ & $\mathbf{2 0 1 6}$ & $\mathbf{2 0 1 7}$ & $\mathbf{2 0 1 8}$ \\
\hline $\begin{array}{l}\text { Little Diggers (primary - ages } \\
\text { 5 to 6) }\end{array}$ & 355 & 763 & 426 & 1817 & 1431 & 858 & 2385 & 2846 & 2758 \\
\hline $\begin{array}{l}\text { Dirt Detectives (primary - } \\
\text { ages 6 to 8) }\end{array}$ & 413 & 484 & 1206 & 2624 & 3012 & 2732 & 2830 & 3429 & 2585 \\
\hline $\begin{array}{l}\text { Pieces of the Past (primary - } \\
\text { ages 10 to 12) }\end{array}$ & 266 & 336 & 373 & 577 & 783 & 1617 & 2143 & 2021 & 2045 \\
\hline $\begin{array}{l}\text { Cesspits and Old Rubbish } \\
\text { (secondary - ages 12 to 14) }\end{array}$ & 2046 & 1703 & 3033 & 3119 & 3858 & 2784 & 1905 & 2103 & 1846 \\
\hline $\begin{array}{l}\text { Shopfront to Western Front } \\
\text { (secondary - ages 14 to 16) }\end{array}$ & - & - & - & - & - & 462 & 455 & 915 & 658 \\
\hline $\begin{array}{l}\text { Groundwork } \\
\text { (secondary - ages 16 to 18) }\end{array}$ & 538 & 475 & 529 & 614 & 432 & 584 & 374 & 300 & 285 \\
\hline $\begin{array}{l}\text { Groundwork Extended } \\
\text { (secondary - ages 16 to 18) }\end{array}$ & - & - & - & - & - & - & - & 310 & 290 \\
\hline
\end{tabular}

\section{Analysis}

- Dirt Detectives is our most popular primary program because 'First Settlement' is taught in Year 4 and students can participate in the simulated excavation.

- Little Diggers is popular with Early Years students because they enjoy the active learning of excavation and the excitement of discovery.

- Cesspits and Old Rubbish is our most popular secondary program. Teachers tell us students like learning about the 'horrible history' aspects of cesspits, latrines, plague and slums!

- The number of senior history students attending the Groundwork programs has increased since 2017 when archaeology topics, specifically The Big Dig, were introduced into the NSW Year 11 Modern History syllabus. 


\section{Feedback: What Teachers Like}

In this section, Education and Interpretation Officer Alison Frappell reports on research she conducted on feedback provided by teachers from 2010 to 2018. Data were collected from feedback forms which are emailed to teachers after their visit, so they have adequate time to observe its impact, discuss what their students learned and reflect on the experience.

Feedback from teachers is invaluable because it tells us what we are doing well, and how we might improve. We also use teacher feedback to modify and improve our programs, so they cater to students' learning needs.

Qualitative responses reported here were selected from teacher feedback from 2016 to 2018 which was analysed to identify broad trends in teachers' thinking about the archaeology education programs and their impact on student learning. Teachers identified four main factors that they and their students most liked about the learning programs:

\section{Factor 1. Direct links to the curriculum}

Preliminary focus group research conducted in 2009 prior to the opening of the Education Centre told us that teachers rarely book education excursions (field trips) that are not directly relevant to what their students are required to study at school. The education programs were therefore designed with clear and relevant links to the requirements of the Australian Curriculum and the NSW history syllabuses, from Kindergarten to Year 12.

Teachers identified curriculum linkage and relevance as one of the strengths of the programs. They provided comments such as: "Very specific to HSIE [History] learning outcomes." (Pieces of the Past); "Site was excellent. Linked very well to the curriculum. Great hands on experience for the students." (Shopfronts to Western Front).

Primary teachers said they were pleased that Australian history is now mandatory in the Australian Curriculum and that archaeology is now included. One teacher reported that her students now think "digging" archaeologists are "way more impressive" than "book reading" historians! Another teacher added an additional note to her feedback saying she observed that her students were more engaged with exploring difficult historical terms and concepts on a 'real' historical archaeology site than in the classroom because it was so practical.

The example below demonstrates how our most popular primary program Dirt Detectives is aligned to the learning requirements of the current NSW history syllabus, which is based on the Australian Curriculum. 
NSW Syllabus for the Australian Curriculum History, Stage 2 (Years 3 and 4)

Dirt Detectives Program (ages 8 to 10 years)

Key inquiry questions

- Why did the great journeys of exploration occur?

- Why did Europeans settle in Australia?

- What was the nature and consequences of contact between Aboriginal and/or Torres Strait Islander people and early traders, explorers and settlers?

Dirt Detectives inquiry question

- What was life like for convicts who lived in The Rocks?

\begin{tabular}{|l|l}
\hline Learning Outcomes & Historical knowledge \\
\hline
\end{tabular}

- Describes people, events and actions related to world exploration and its effects HT2-3

- Describes and explains effects of British colonisation in Australia HT2-4

- Applies skills of historical inquiry and communication HT2-5

\begin{tabular}{|c|c|}
\hline $\begin{array}{l}\text { First contacts } \\
\text { Stories of the First Fleet, } \\
\text { including reasons for the } \\
\text { journey, who travelled to } \\
\text { Australia, and their } \\
\text { experiences following arrival } \\
\text { (ACHHK079) }\end{array}$ & $\begin{array}{ll}\text { - } & \text { Continuity and change } \\
\text { - } & \text { Cause and effect } \\
\text { - } & \text { Perspectives } \\
\text { - } & \text { Empathetic } \\
& \text { understanding } \\
\text { - } & \text { Significance }\end{array}$ \\
\hline
\end{tabular}

\section{Factor 2. “It's Real".}

Research indicates that emotional connections to artefacts and archaeology can have a profound effect on children's long-term memory and learning (Hudson and Fivush 1991). A haptic, sensory experience can awaken a child's inquisitiveness and sense of wonder, as well as give them an emotional link to the people who owned, made or used the artefact. Not only do we want children to feel physically connected to the past, we want them to feel connected to the present, to their own immediate life experience.

Children's memories of an experience can be triggered by visual, aural and olfactory stimuli, as well as memories of the social interactions that took place on the day: remembering the fun of being with friends on the excursion, what they ate on the day ("when we went to McDonald's") and most importantly, whether or not they liked the educator.

When they first arrive at The Big Dig and look across the site at the archaeological remains, students often say, "Oh Wow!" and "are they still digging?". They quickly realise the site is 'real' and begin trying to make sense of the archaeological remains.

The first activity of most of our programs (depending on the age of the children) is a guided tour of the archaeological remains of houses where people lived, worked and died. This is so that students orient themselves spatially and have an immersive, sensory experience of the site. As they look over the archaeological site from the balcony of the Archaeology Education Centre, students are asked to observe the surrounding landscape, how the Sydney sandstone bedrock gave the area its name, 'The Rocks', and how this sandstone was cut and terraced to create early buildings, gradually transforming the natural environment. 


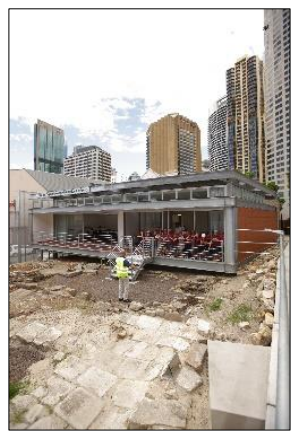

Insert photo: Figure 2

They then stand within the foundations of houses and are prompted by guides to gauge the size and layout of the buildings and rooms (unusually small by today's standards), then consider what the archaeological and historical sources can tell us about the families who once lived there: how do the spaces compare to their own home, their bedroom and their family's living spaces? They are encouraged to picture themselves living "back in time'could they cope with living in such small spaces with so many people?

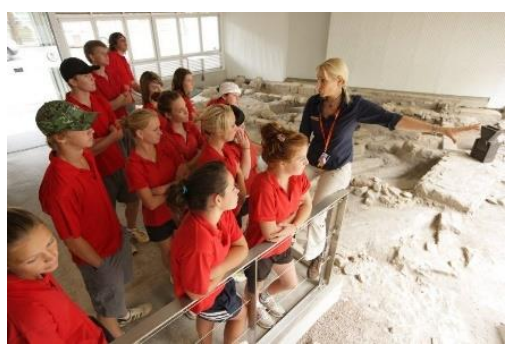

Insert photo: Figure 3

Back in the Archaeology Education Centre, students sit on chairs at tables, or on floor mats (depending on their age and size) to analyse artefacts that were excavated from the site. When we were planning the programs there was some concern that students might damage the artefacts, so a collection of reasonably robust unstratified artefacts was selected for our handling collection. These fears were soon allayed when we saw how carefully students treated the artefacts. We found that, because students know the artefacts are "real' and from the site, they tended to handle them with respect. Ironically, the trays in which the artefacts are presented on the tables and cardboard boxes in which they are stored have been subjected to quite a lot of rough handling and graffiti!

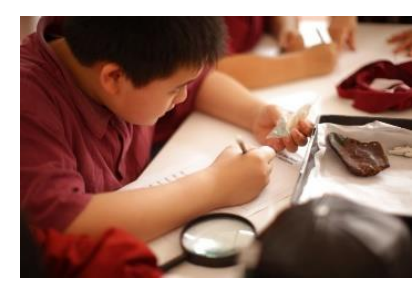

Insert photo: Figure 4

The artefact analysis activity is undertaken in groups, accompanied by a worksheet with questions that prompt students to focus on different features of the artefact. If time permits, 
one student from each group will give a short presentation to the rest of the class about the artefact - what it is? how it was made? who made it? how it was used? and anything else they found important or intriguing.

In our Shopfronts to Western Front program (ages 14 to 16 years), secondary students undertake more sophisticated analytical tasks such as placing bottles in chronological and typological order, identifying the technological shift from handmade to mechanised bottle production, and identifying different coloured and shaped bottles that were specifically made to indicate their contents (such as medicine bottles).

Teachers told us that, "The children were engaged and loved visiting the site, hearing the stories, and handling the artefacts. They were excited from the minute we arrived. The highlight was the artefacts analysis and the digging" (Pieces of the Past). "History is all around us and from just one artefact we can learn so much" (Groundwork). Overall, teachers said that students found it easier to understanding the sometimes-complex differences between archaeology and history, between primary and secondary sources, and questioning source reliability, when participating in active learning and having first-hand contact with artefacts used by 'real' people who once lived on the site.

\section{Factor 3. Working like an Archaeologist}

Teachers tell us students really enjoy "working like an archaeologist", whether they are taking part in a simulated excavation (ages 5 to 8 years) or analysing authentic artefacts from the site (ages 5 to 18 years). However, we are very mindful that an over emphasis on 'digging' could give students the impression that this is the only thing professional archaeologists do; therefore, we make a point of explaining that 'digging' is only one part of a much bigger process of investigation. Other activities, such as artefact analysis, interpretation and site conservation are integral to the entire sequence of archaeological research, and these are the sorts of activities students participate in during their visit.

The simulated excavation is located inside the restored ruins of a small stable which have been incorporated into the architecture of the Archaeology Education Centre. Due to the limited space available inside the ruins, only children up to the age of 8 years (Little Diggers and Dirt Detectives) can participate in the simulated excavation activity.

The space has been filled with sand, and the simulated dig is set up as a simplified field site with four 'trenches'. Students work in small teams (between 3 and 5 children), taking turns to excavate and record the artefacts or building remnants they have found in their trench, sometimes even recording the depth. Children in the early stages of literacy development draw pictures of what they have uncovered. Teachers and SLA guides help them write simple words, such as 'nail', 'pot', 'shoe' to help describe the artefacts they have 'discovered'.

Young children are always excited when they begin the activity, so SLA guides usually begin by calming them down and directing their excitement and energy to the 'serious work' they are about to undertake. They emphasise that they must work "slowly and carefully like a real archaeologist", taking care not to destroy the artefact or context as they go. They explain that artefacts come from a special place (context), and that they must think about them alongside the other finds from that area so they can find out what people were doing in this place a long time ago. 
The artefacts are then brought back into the classroom and placed on a large mat which has a map of the site printed on it. This helps students to recontextualise the artefacts so they can work out how that space might have been used in the past. Teachers commented that there were "good links between the archaeological skills of mapping, digging and identifying. Boys loved digging" and that "the students were exposed to content, artefacts and sites that we cannot provide them in the classroom. Thoroughly effective excursion for our students" (Pieces of the Past).

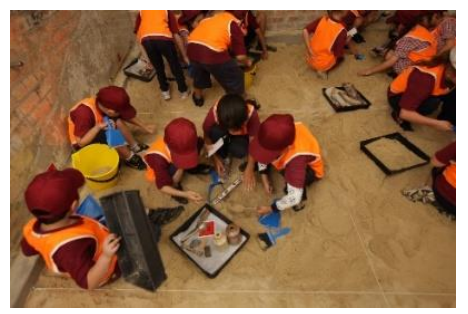

Insert photo: Figure 5

\section{Factor 4. Using inquiry learning}

Historical inquiry is the heuristic used by historians to study the past. It is the process of developing knowledge and understanding in history by asking questions about the past, and applying skills associated with analysing, interpreting and evaluating sources of evidence to develop informed and defensible answers. The Australian Curriculum advises that teachers "should allow for the development of skills through a process of historical inquiry". (ACARA 2009: 5).

During the process of historical inquiry, students ask historical questions, identify contradictions and conflicts, and develop interpretations supported by historical evidence. Fundamental to the inquiry is the interrogation and critical evaluation of primary sources, which can be written, visual or archaeological. Students analyse written primary sources such as eyewitness accounts, diaries and newspaper reports, and images such as photographs, postcards and paintings. At The Big Dig they examine artefacts such as ceramics, metal, glass bottles, leather shoes, buttons and porcelain 'Frozen Charlotte' dolls.

Inquiry pedagogy underpins learning at The Big Dig Archaeology Education Centre, and teachers tell us students their respond well to this investigative approach because it is the same approach they take in their own classrooms. SLA guides use inquiry learning to teach critical and creative thinking, a skill not only useful for interpreting the past, but also a $21 \mathrm{st}$ century life skill.

Some of the same questions the archaeologists proposed in their planning for the 1994 excavations are now being asked by students during our programs. For example, in Dirt Detectives the inquiry questions for both the education program and the Australian Curriculum are: What do we know about the lives of people in Australia's colonial past and how do we know? How did an Australian colony develop over time and why? How did colonial settlement change the environment? (see above)

Teachers have responded positively to this pedagogy: "We were interested in a historical inquiry focus. This was definitely covered in the context of the program. There was a great 
mix of stories and hands on activities." (Dirt Detectives). The program was "highly engaging for students. Love the fact that history was alive." (Cesspits and Old Rubbish).

\section{Conclusion}

In his welcome letter to the World Archaeology Congress (WAC-8) in Kyoto in 2016where this paper was originally presented-Professor Tsude Hiroshi asked all attendees to consider the meaning and relevance of archaeology and heritage in contemporary society, and how we might best encourage and enact social, environment and economic sustainability.

Sydney Harbour YHA and The Big Dig Archaeology Education Centre strive to be economically, environmentally and socially sustainable. Guests staying at the hostel, the site's contemporary use, make a small financial contribution to The Big Dig sinking fund, which is used to support conservation and interpretation of the site, including The Big Dig educational programs.

The hostel has won multiple awards for tourism and sustainability, such as the Australian Tourism Awards Best Hostel 'Hall of Fame' award, the 2011 Australian Sustainability Awards, and the 2011 NSW National Trust award for Best Education Program. However, of equal importance is the social sustainability aspect, and the award proudly on display at the ground floor entrance is the UNESCO Cultural Heritage Conservation Award for Innovation, awarded in 2011.

Through our archaeology education programs, we strive to teach the next generations to value and respect what remnants of the past are left to us, to take a longer-term view of our multicultural society and be aware of how the actions of today might influence our collective future. We believe the best way young people can achieve this is through empathy, and archaeology is ideally suited to this task. We end with a quote from one of our students: "When I touch things that belong to people who lived centuries ago, I feel shivers up and down my spine; I feel really connected to them." 


\section{References}

Australian Curriculum and Assessment Reporting Authority (ACARA)

2009. Shape of the Australian Curriculum: History

Hudson, J.A. and Fivush, R.

1991. As Time Goes By: Sixth Graders Remember a Kindergarten Experience. Applied Cognitive Psychology, Vol. 5, 347-360.

Karskens, G.

1999. Inside the Rocks: The Archaeology of a Neighbourhood. Hale and Iremonger, Sydney.

NSW Education Standards Authority (NESA)

2018. Ancient History Syllabus and Modern History Syllabus. Electronic document, https://www.educationstandards.nsw.edu.au/wps/portal/nesa/11-12/stage-6-learning areas/hsie. Accessed 4 February 2019

NSW Government

2016 Cumberland Street Dig Site, Archaeology, Statement of Significance. Electronic document, http://www.shfa.nsw.gov.au/sydney-About_us-Heritage roleHeritage_and_Conservation_Register.htm\&objectid=159. Accessed 4 February 2019.

Sydney Harbour YHA

2019 The Big Dig Archaeology Education Centre. Electronic document, https://thebigdig.com.au/, Accessed 7 February.

Zarmati, L.

2015 Archaeology as Pedagogy at Sydney’s The Big Dig. The Historic Environment 6(2) September:177-91.

Zarmati, L. and Frappell, A.

2009 Beyond Four Walls: Learning Outside, and Even Under The Classroom. Teacher September:6-9. 


\section{List of Figures}

Figure 1. Exterior of Sydney Harbour YHA in The Rocks, Sydney

Figure 2. Students looking over The Big Dig from the balcony of the Archaeology Education Centre

Figure 3. Students standing in the ruins of houses once occupied by families

Figure 4. Student carefully analysing an artefact

Figure 5. Little Diggers working in teams to excavate artefacts

All photos courtesy of Sydney Harbour YHA. 